\title{
Physical Properties of 7-Methyl-1,5,7-triazabicyclo[4.4.0]dec-5-ene (mTBD)
}

\section{Zachariah Steven Baird, et al. [full author details at the end of the article]}

Received: 28 February 2019 / Accepted: 3 July 2019 / Published online: 12 July 2019

(c) The Author(s) 2019

\begin{abstract}
7-Methyl-1,5,7-triazabicyclo[4.4.0]dec-5-ene (mTBD) has useful catalytic properties and can form an ionic liquid when mixed with an acid. Despite its potential usefulness, no data on its thermodynamic and transport properties are currently available in the literature. Here we present the first reliable public data on the liquid vapor pressure (temperature from $318.23 \mathrm{~K}$ to $451.2 \mathrm{~K}$ and pressure from $11.1 \mathrm{~Pa}$ to $10000 \mathrm{~Pa}$ ), liquid compressed density $(293.15 \mathrm{~K}$ to $473.15 \mathrm{~K}$ and $0.092 \mathrm{MPa}$ to $15.788 \mathrm{MPa})$, liquid isobaric heat capacity $(312.48 \mathrm{~K}$ to $391.50 \mathrm{~K})$, melting properties, liquid thermal conductivity $(299.0 \mathrm{~K}$ to $372.9 \mathrm{~K})$, liquid refractive index $(293.15 \mathrm{~K}$ to $343.15 \mathrm{~K})$, liquid viscosity $(290.79 \mathrm{~K}$ to $363.00 \mathrm{~K})$, liquid-vapor enthalpy of vaporization $(318.23 \mathrm{~K}$ to $451.2 \mathrm{~K}$ ), liquid thermal expansion coefficient $(293.15 \mathrm{~K}$ to $473.15 \mathrm{~K}$ ), and liquid isothermal compressibility of mTBD (293.15 K to 473.15). The properties of mTBD were compared with those of other relevant compounds, including 1,5-diazabicyclo(4.3.0)non-5-ene (DBN), 1,8-diazabicyclo[5.4.0]undec-7ene (DBU), and 1,1,3,3-tetramethylguanidine (TMG). We used the PC-SAFT equation of state to model the thermodynamic properties of mTBD, DBN, DBU, and TMG. The PC-SAFT parameters were optimized using experimental data.
\end{abstract}

Keywords Density - mTBD · PC-SAFT · Thermodynamic properties · Vapor pressure

\section{Introduction}

7-Methyl-1,5,7-triazabicyclo[4.4.0]dec-5-ene (mTBD) has a variety of interesting properties. For years it has attracted attention as a catalyst [1-4], and more recently

Electronic supplementary material The online version of this article (https://doi.org/10.1007/s10765019-2540-2) contains supplementary material, which is available to authorized users.

Petri Uusi-Kyyny

petri.uusi-kyyny@aalto.fi

Extended author information available on the last page of the article 
it has been studied for possible use in $\mathrm{CO}_{2}$ capture [5, 6]. It can also form an ionic liquid when mixed with an acid, and some of these ionic liquids are able to dissolve cellulose [7]. This ability to dissolve cellulose is the basis for the IONCELL-F process, which produces textile fibers from woody biomass by using ionic liquids like 7-methyl-1,5,7-triazabicyclo[4.4.0]dec-5-enium acetate as a solvent [8, 9].

Although mTBD has properties that make it an industrially important chemical, no data about its thermodynamic properties can be found in the literature. Additionally, mTBD is one of a family of guanidine superbases [3] and information about it could also be useful in understanding these superbases in general. The only values publicly available are a density and a single vapor pressure value given on some safety data sheets, and their accuracy is questionable, largely because the vapor pressure units differ depending on the safety data sheet.

To address this gap, we have measured the liquid vapor pressure using two experimental methods (temperature from $318.23 \mathrm{~K}$ to $451.2 \mathrm{~K}$ and pressure from $11.1 \mathrm{~Pa}$ to $10000 \mathrm{~Pa}$ ), compressed liquid density $(293.15 \mathrm{~K}$ to $473.15 \mathrm{~K}$ and $0.092 \mathrm{MPa}$ to $15.788 \mathrm{MPa})$, liquid isobaric heat capacity $(312.48 \mathrm{~K}$ to $391.50 \mathrm{~K}, 0.36 \mathrm{MPa})$, melting properties, liquid thermal conductivity $(299.0 \mathrm{~K}$ to $372.9 \mathrm{~K})$, liquid refractive index (293.15 K to $343.15 \mathrm{~K}$ ), and liquid viscosity (290.79 K to $363.00 \mathrm{~K}$ ) of mTBD. The heat of vaporization (liquid-vapor), liquid thermal expansion coefficient, and liquid isothermal compressibility were also calculated from the experimental data. The thermodynamic properties of mTBD were then modeled using the PC-SAFT equation of state [10]. The measurement were made at atmospheric pressure $(0.1 \mathrm{MPa})$, if not specified otherwise.

\section{Methods}

\subsection{Preparation and Purity of the mTBD}

Three different samples of 7-methyl-1,5,7-triazabicyclo[4.4.0]dec-5-ene (CAS number: 84030-20-6, structure in Fig. 1) were used. The first was prepared at the University of Helsinki. The second was purchased from BOC Sciences (Shirley, NY, USA). The third was a portion of the second sample that was distilled to further purify it (see Sect. 2.6) (Table 1).

Fig. 1 Structure of

7-methyl-1,5,7-

triazabicyclo[4.4.0]dec-5-ene

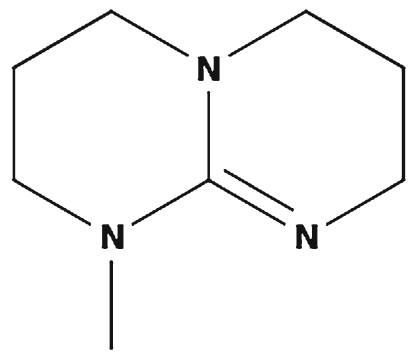


Table 1 Information about the 7-methyl-1,5,7-triazabicyclo[4.4.0]dec-5-ene samples used in this work

\begin{tabular}{lllll}
\hline Sample number & Source & Purification & Water content (wt\%) & Purity (wt\%) \\
\hline 1 & University of Helsinki & None & 0.03 & $>99.5$ \\
2 & BOC Sciences & None & 0.04 & $97.2 \pm 1$ \\
3 & BOC Sciences & Distillation & 0.01 & $98.3 \pm 1.7$ \\
\hline
\end{tabular}

The purity of the mTBD samples was analyzed using capillary electrophoresis (CE). Experiments were carried out with an Agilent 7100 CE system from Agilent Technologies (Santa Clara, CA, USA) equipped with a diode-array detector (detection at $200 \mathrm{~nm}, 214 \mathrm{~nm}$, and $238 \mathrm{~nm}$ ) and an air-cooling device for the capillary cassette. Uncoated fused silica capillaries were from Polymicro Technologies (Phoenix, AZ, USA). Dimensions were $50 \mu \mathrm{m}$ internal diameter and $375 \mu \mathrm{m}$ outer diameter. The length of the capillary up to the detector was $0.300 \mathrm{~m}$, and the total length was $0.385 \mathrm{~m}$. A Mettler Toledo $\mathrm{pH}$ meter (Columbus, Ohio, USA) was used to adjust the $\mathrm{pH}$ of the electrolyte solutions.

The capillary was coated with polybrene. Prior to the coating, the bare fused silica capillary was pretreated by flushing it for $10 \mathrm{~min}$ with $1 \mathrm{M} \mathrm{NaOH}$, followed by rinsing with water for $10 \mathrm{~min}$ at a pressure of $94000 \mathrm{~Pa}$. To diminish the adsorption of positively charged mTBD on the negatively charged fused silica capillary wall, the capillary was flushed for $22 \mathrm{~min}$ with a $1 \mathrm{w} / \mathrm{w} \%$ of polybrene solution [11]. Further, a voltage of $3 \mathrm{kV}$ was applied for $20 \mathrm{~min}$ with both capillary ends immersed in the vials with the coating solution. To remove unreacted polybrene molecules, the capillary was rinsed for $10 \mathrm{~min}$ with water and sodium acetate buffer solution $(\mathrm{pH} \mathrm{4}$; ionic strength of $25 \mathrm{mM}$ ), respectively. In order to regenerate the coating surface, a fast 3 -step recoating of the capillary was performed after every eight CE run. This was done by firstly flushing the capillary for $1 \mathrm{~min}$ with the coating solution, then keeping the system steady state for $1 \mathrm{~min}$ (waiting step), and finally flushing the capillary with water for $1 \mathrm{~min}$.

The polybrene-coated capillary was characterized by checking the electro-osmotic flow. Thiourea at a concentration of $0.5 \mathrm{mM}$ dissolved in a sodium acetate buffer $(\mathrm{pH}$ 4 ; ionic strength of $20 \mathrm{mM}$ ) was used as a neutral electro-osmotic flow marker in all measurements. A set of mTBD solutions at a concentration range of $0.01 \mathrm{mg} \cdot \mathrm{mL}^{-1}$ to $0.2 \mathrm{mg} \cdot \mathrm{mL}^{-1}$ was used to prepare the mTBD calibration curve. A negative voltage of $25 \mathrm{kV}$ was applied across the capillary. All samples were introduced at $1000 \mathrm{~Pa}$ for $10 \mathrm{~s}$. Before each run, the capillary was rinsed for 2 min with a sodium acetate buffer ( $\mathrm{pH} 4$; ionic strength of $25 \mathrm{mM}$ ). The electrophoretic runs were repeated at least 5 times. All results were evaluated with the ChemStation software purchased from Agilent Technologies (Santa Clara, CA, USA).

The water content of the mTBD was determined using Karl Fischer titration. A DL38 Karl Fischer Titrator (Mettler Toledo) was used along with the Hydranal Composite $5 \mathrm{~K}$ titrant and the Hydranal Medium K solvent solution (both from Fluka Analytical). 
The first sample had a purity greater than $99.5 \mathrm{wt} \%$. The second sample had a purity of $97.2 \pm 1 \mathrm{wt} \%$ and contained $1.6 \pm 0.1 \mathrm{wt} \%$ of the non-methylated 1,5,7triazabicyclo[4.4.0]dec-5-ene as an impurity. The third sample had a purity of $98.3 \pm 1.7 \mathrm{wt} \%$. Trace amounts of TBD were still detected in the first and third samples, but the amount was below the limit of quantitation, which was $0.0025 \mathrm{mg} \cdot \mathrm{mL}^{-1}$. The electropherograms are presented in the Electronic Supplementary Material. Pure mTBD is a colorless liquid at room temperature, and the first and third samples were initially colorless. However, it was noticed that over time the mTBD sample took on a yellow color. Even small amounts of an impurity can cause a color change. To see if the purity had significantly changed, the first sample was reanalyzed when the yellow color was noticed, but no impurities were detected. The yellow color may have come from small amounts of oxidation products, which have been observed for a similar base: DBN [12]. The second sample was yellow when obtained. The first sample was used for most of the measurements. Only the heat capacity measurements and second and third set of viscosity measurements were performed with the second sample. The third sample was only used for some of the vapor pressure measurements.

mTBD is hygroscopic and can also react with $\mathrm{CO}_{2}$ in the air, so to minimize the absorption of these compounds the mTBD was stored in closed containers. When it was necessary to get some of the mTBD, the containers were opened only briefly.

In addition to mTBD, several different chemicals were used in running, calibrating, or checking the devices used in this study, and a full list of these chemicals and their suppliers can be found from the Electronic Supplementary Material accompanying this article.

\subsection{Liquid Compressed Density}

Compressed densities of mTBD were measured using a DMA HP density meter (Anton Paar, Graz, Austria). The pressure in the density meter was measured using a UNIK 5000 pressure sensor (GE, Boston, MA, USA). For calibrating this pressure sensor, a MC2-PE calibrator with an EXT600 external pressure module was used (Beamex, Pietarsaari, Finland), and these had been calibrated by Beamex. The standard uncertainty of the pressure data is $3100 \mathrm{~Pa}$ (expanded uncertainty of $6300 \mathrm{~Pa}$ at the $95 \%$ level). For the measured temperature, the manufacturer only states that its accuracy is better than $0.1 \mathrm{~K}$. The mTBD was degassed for about $30 \mathrm{~min}$ in a roundbottomed flask before being fed into the density meter. This was done by placing the sample in an ultrasonic bath and removing the gases in the system using a vacuum pump.

The DMA HP density meter was calibrated using nitrogen and water, and the reference values for these compounds were taken from reference equations of state $[13,14]$. For performing calculations with these equations of state, CoolProp's [15] Python package was used. The NIST thermophysical properties calculator [16] also implements the same equations of state, so CoolProp's functions were verified by manually comparing the results of the two programs at multiple temperatures and 
pressures. The values were the same in all instances. The parameters for the calibration equation were optimized using the differential evolution solver [17] implemented in the SciPy package [18] for Python. The root mean squared error was used as the objective function. From the calibration results, the standard uncertainty of the device was estimated to be $0.040 \mathrm{~kg} \cdot \mathrm{m}^{-3}$ (expanded uncertainty of $0.082 \mathrm{~kg} \cdot \mathrm{m}^{-3}$ at the $95 \%$ level).

Measurements were performed on 2 separate days, and the device was cleaned and refilled before the second set of measurements. Eight of the data points were measured on both days, and the deviation between these repeat measurements was within the expanded uncertainty of the device.

\subsection{Refractive Index}

A Dr. Kernchen Abbemat digital refractometer (Anton Paar, Graz, Austria) was used for refractive index measurements. This refractometer measures at a wavelength of $598.3 \mathrm{~nm}$. The standard uncertainty of the refractometer was calculated to be 0.00034 (expanded uncertainty of 0.00078 at the $95 \%$ level) by using measured and reference values for water at $25^{\circ} \mathrm{C}[19]$.

\subsection{Liquid Viscosity}

For measuring the viscosity, a LVDVE230 rotational viscometer was used (Brookfield, Middleboro, MA, USA). The temperature in the measurement cylinder was controlled using a water bath. For measuring the temperature, probes were placed in the inlet and outlet of the heating water from the measurement cylinder. The temperature of the measurement was calculated as the average of these two temperatures. The difference between the inlet and outlet temperatures was less than $0.05 \mathrm{~K}$ at room temperature and less than $0.2 \mathrm{~K}$ at higher temperatures. The viscometer was left to stabilize at each measurement temperature for at least $30 \mathrm{~min}$ before values were recorded. The viscometer was calibrated using a Brookfield viscosity standard (Lot number 012610), water, and $n$-hexadecane. The deviation between the calibrated experimental values and reference data was used to calculate the uncertainty of the device. The standard uncertainty was $5.4 \%$, and the expanded uncertainty (95\% level) was $12 \%$.

Three measurements were performed for mTBD. The first measurements were done with a setup that was open to the atmosphere. To confirm that moisture absorbed from the air did not affect the measurements, a third run was carried out in which the viscometer was covered with a large piece of flexible plastic that was draped over the instrument and dry air was continually added to the space around the viscometer. This lowered the relative humidity around the viscometer during the experiment. The results of the three different experiments matched to within the uncertainty of the device, so any absorption of water did not noticeably affect the results. 


\subsection{Liquid Vapor Pressure with the Gas Saturation Method}

The gas saturation method was used for measuring the vapor pressure of mTBD at temperatures below $386.16 \mathrm{~K}[20,21]$. The sample was placed in a glass vessel that contained spherical glass beads. This vessel was placed in a gas chromatography oven, which maintained a stable temperature (temperature remained within $\pm 0.01 \mathrm{~K}$ ). A flow of nitrogen was introduced (at $20 \mathrm{mln} \cdot \mathrm{min}^{-1}$ ), which flowed through the cell and became saturated with the vaporized $\mathrm{mTBD}$. The flow rate of nitrogen was maintained using a flow controller (Alicat Scientific, Tucson, AZ, USA). The flow rate of the nitrogen was measured using a bubble meter (standard uncertainty of $0.020 \mathrm{ml} \cdot \mathrm{min}^{-1}$, expanded uncertainty of $0.045 \mathrm{ml} \cdot \mathrm{min}^{-1}$ at the $95 \%$ level). The vessel was held at the set temperature for a period of time (usually $24 \mathrm{~h}$ or more), and then the vessel was removed and weighed to determine the mass lost. From these data, the vapor pressure was calculated using Eq. 1

$$
P=\frac{\frac{m}{W}}{\left(\frac{m}{W}+\frac{t V P_{\mathrm{atm}}}{T_{\mathrm{room}} R}\right)} \cdot\left(P_{\mathrm{atm}}+\Delta P_{\mathrm{loss}}\right),
$$

where $\mathrm{P}$ is the vapor pressure $(\mathrm{Pa}), \mathrm{m}$ is the mass of the test chemical (mTBD) that leaves the cell $(\mathrm{g}), \mathrm{W}$ is the molar mass of the test chemical $\left(\mathrm{g} \cdot \mathrm{mol}^{-1}\right), \mathrm{t}$ is the duration of the measurement (min), $\mathrm{V}$ is the volumetric flow rate of the carrier gas (in this case, nitrogen) in units of $\mathrm{L} \cdot \mathrm{min}^{-1}, \mathrm{P}_{\mathrm{atm}}$ is the atmospheric pressure at the place and time the experiment is carried out $(\mathrm{Pa}), \mathrm{T}_{\text {room }}$ is room temperature $(\mathrm{K}), \mathrm{R}$ is the ideal gas constant, and $\Delta \mathrm{P}_{\text {loss }}$ is the pressure drop over the gas saturation cell (assumed to be zero for our measurements). More details about the gas saturation method can be found from other references [20, 21].

The inlet and outlet of the glass vessel were covered with paraffin film when removing it from the oven for weighing. This was done to ensure that the mTBD did not absorb water from the air. Also, when the oven was heating up or cooling down, a small flow of nitrogen was still applied $\left(0.5 \mathrm{mln} \cdot \mathrm{min}^{-1}\right)$ to reduce the amount of outside air that entered the cell. When measuring the masses and the flow rate, repeat measurements were made (usually 8) and the average was recorded as the final value. Atmospheric pressure was measured using the MC2-PE pressure calibrator. Temperatures (both cell and room temperatures) were measured using a Systemteknik S2541 thermometer (Frontec) with calibrated Pt-100 temperature probes (Frontec).

Uncertainties were calculated using a Monte Carlo method (see ISO/IEC Guide 98-3) [22]. Distributions were specified for eight different parameters that could potentially affect the vapor pressure value, including the purity of the mTBD. Values were then selected from these distributions and used to calculate a vapor pressure value. This process was repeated 1 million times for each experimental data point, and the resulting distributions were then used for estimating the uncertainties. The Python code used for this calculation can be found from the OSF project for this study (https://osf. io/efds6/). 


\subsection{Liquid Vapor Pressure with the Distillation Method}

Vacuum distillation was used for measuring the vapor pressure of mTBD at temperatures above $380 \mathrm{~K}$. Two different distillations were performed, one at the University of Helsinki and one at Aalto University.

The distillation at the University of Helsinki was performed using mTBD that had already been distilled once. A simple distillation was performed, that is, no column was used. A water jet pump was used to apply a vacuum, and a needle valve was used to introduce a small leak to allow the pressure to be regulated. The temperature of the condensate was measured using a Type $\mathrm{K}$ thermocouple, which had an expanded uncertainty of $\pm 1 \mathrm{~K}$. The expanded uncertainty of the vacuum gauge was estimated to be the greater of $10 \%$ or $200 \mathrm{~Pa}$.

At Aalto University, the distillation was performed with the mTBD obtained from BOC Sciences, which had an initial purity of $97 \mathrm{wt} \%$. A $0.55 \mathrm{~m}$ Vigreux column was used. When measuring the vapor pressure, the column was operated at total reflux. The condensers were cooled using a circulating bath that was set to $290 \mathrm{~K}$. A vacuum pump was used to reduce the pressure, and a small leak was introduced using a needle valve in order to adjust the pressure. The temperature was measured using a Nokeval temperature probe (Nokia, Finland), which had been calibrated against an RTD temperature probe that had been calibrated at the Finnish National Metrology Institute (Espoo, Finland). Based on this calibration, the standard uncertainty of the temperature probe was estimated to be $0.06 \mathrm{~K}$ (expanded uncertainty of $0.12 \mathrm{~K}$ at the $95 \%$ level). A Vacuuview pressure gauge (Vacuubrand, Wertheim, Germany) was used to measure the pressure. It was calibrated using the MC2-PE pressure calibrator, and based on this calibration the standard uncertainty was calculated to be $14 \mathrm{~Pa}$ (expanded uncertainty of $31 \mathrm{~Pa}$ at the $95 \%$ level).

The overall uncertainty of the vapor pressures measured using distillation was calculated by combining the uncertainties of the temperature measurements and pressure gauges. This was done using a Monte Carlo method with sampling repeated 1 million times (see ISO/IEC Guide 98-3) [22].

\subsection{Heat Capacity}

For the heat capacity measurements, a C80 Calvet calorimeter (Setaram, Caluire, France) was used. The measurement cell was made of Hastelloy C276 (S60/1512) and had a volume of $14 \mathrm{~mL}$. The instrument was calibrated using water and nitrogen. Heat capacity measurements were performed at a constant pressure of $360000 \mathrm{~Pa} \pm 20000 \mathrm{~Pa}$. The vapor pressure of mTBD is substantially lower than the measurement pressure, thus ensuring that the sample is in the liquid phase.

Measurements were performed in a stepwise manner. The temperature was first held steady at a specified temperature. Then the temperature was increase $10 \mathrm{~K}$, and during this ramp the difference in temperature between the reference and sample cells was recorded. The total heat flow for a given step change was calculated via integration, and the heat capacity was then calculated using Eq. 2 [23] 


$$
C_{\mathrm{P} 2}=\frac{C_{\mathrm{P} 1} \cdot \rho_{1}}{\rho_{2}} \cdot\left(\frac{Q_{2}-Q_{0}}{Q_{1}-Q_{0}}\right) .
$$

In Eq. $2, \rho_{1}$ is the density for the standard (water in our case); $\rho_{2}$ is the density for the sample; $C_{\mathrm{P} 1}$ is the heat capacity of the standard (water); $C_{\mathrm{P} 2}$ is the heat capacity of the sample; and $Q_{0}, Q_{1}$ and $Q_{2}$ are the measured heats of the blank (nitrogen), standard, and sample, respectively. The reference values for the heat capacity of water were calculated using the NIST thermophysical properties calculator [16], which is based on the IAPWS95 equation of state [14]. The temperature was taken as the average of the initial and final temperature of the step.

The heat capacity of water and a 3 molal aqueous $\mathrm{NaCl}$ solution were measured to check the performance of the calorimeter. Measured data were compared to reference values from the IAPWS95 equation of state [14], which can be accessed from the NIST website [16], and to values from Clarke and Glew [24]. Based on this check, the standard uncertainty of the measurements was calculated to be $0.0028 \mathrm{~J} \cdot \mathrm{g}^{-1} \cdot \mathrm{K}^{-1}$ (expanded uncertainty of $0.0057 \mathrm{~J} \cdot \mathrm{g}^{-1} \cdot \mathrm{K}^{-1}$ at the $95 \%$ level). At temperatures above $373 \mathrm{~K}$, the deviation between measured and reference values increased. The measured data for water and $\mathrm{NaCl}$ can be found from the heat capacity file on the OSF project page (https://osf.io/zyr5t/).

\subsection{Melting Properties}

Differential scanning calorimetry (DSC) was used to determine the melting point and enthalpy of fusion of mTBD. The DSC measurement was performed on a Q2000 DSC instrument (TA Instruments, New Castle, DE, USA) equipped with a two-stage refrigerated cooling system. Analysis was run on an mTBD sample with a mass of $9.33 \mathrm{mg}$, which was hermetically sealed in a $50 \mathrm{mg}$ Tzero aluminum pan. The pan was filled and sealed in a glove box that was filled with dry air to avoid absorption of water. Inside the DSC chamber, which was filled with $\mathrm{N}_{2}$, the sample was cooled $\left(\right.$ rate $5 \mathrm{~K} \cdot \mathrm{min}^{-1}$ ) to $213 \mathrm{~K}$ to crystallize the sample and then heated (rate $1 \mathrm{~K} \cdot \mathrm{min}^{-1}$ ) to observe the melting point. A lower heating rate provides better correspondence between the DSC temperature and the actual temperature of the sample. The onset of the melting peak on the DSC thermogram was taken to be the melting point, and the heat of fusion was calculated by integrating to find the area of the peak. Based on reference and measured values for water, acetic acid, and $n$-hexadecane, the standard uncertainty of the melting point measurements was calculated to be $0.49 \mathrm{~K}$ (expanded uncertainty of $1.2 \mathrm{~K}$ at the $95 \%$ level). The standard uncertainty for the enthalpy measurement was $10 \mathrm{~J} \cdot \mathrm{g}^{-1}$ (expanded uncertainty of $26 \mathrm{~J} \cdot \mathrm{g}^{-1}$ at the $95 \%$ level).

\subsection{Thermal Conductivity}

The transient hot wire method was utilized to measure the thermal conductivity of mTBD. The device was a THW-L2 Liquid Thermal Conductivity Meter from Thermtest Inc. (Fredericton, NB, Canada). The THW method assumes isotropic fluids 
and the Fourier heat conduction equation for transient testing can then be formulated as Eq. 3 [25]

$$
\rho \cdot C_{\mathrm{p}} \cdot \frac{\partial T}{\partial t}=\lambda \cdot \nabla^{2} T .
$$

In Eq. $3, \lambda$ is the thermal conductivity, $\rho$ is the density, $\mathrm{T}$ is temperature, $\mathrm{t}$ is time, and $C_{\mathrm{p}}$ is the specific heat capacity. During testing, the sensor wire is heated with step-function-like constant effect that lasts less than $2 \mathrm{~s}$, and the resulting temperature rise is recorded. If the wire length and sample volume can be considered infinite during the test time, the thermal conductivity can then be calculated from the temperature rise equation, as derived from Eq. 3:

$$
\Delta T\left(r_{0}, t\right)=\frac{q}{4 \cdot \pi \cdot \lambda} \cdot \ln \left(\frac{4 \cdot \kappa \cdot t}{r_{0}^{2} \cdot e^{\gamma}}\right) .
$$

Here $\kappa$ is the thermal diffusivity, $\mathrm{r}_{0}$ the wire radius, $\mathrm{q}$ the heat transfer rate, and $\gamma$ is Euler's constant [26, 27]. However, the experimental setup deviates from an ideal system and the results are therefore corrected with an offset calibration, which allows for accurate testing of the thermal conductivity but hinders accurate measurement of the diffusivity. For calibration, deionized water was used.

The expanded uncertainty of the measured values was estimated to be $5 \%$, which for the values presented here is $\pm 0.007 \mathrm{~W} \cdot \mathrm{m}^{-1} \cdot \mathrm{K}^{-1}$.

For successful testing of the mTBD samples, a stainless-steel container was used to hold the sample. Aluminum had to be avoided because corrosion occurred with aqueous solutions of mTBD. To prevent degradation of the probe structure, the sensor body was coated with epoxy. About $25 \mathrm{~mL}$ of the sample was used for each test. Testing was performed at $298 \mathrm{~K}, 323 \mathrm{~K}, 348 \mathrm{~K}$, and $373 \mathrm{~K}$.

\subsection{Modeling Using PC-SAFT Equation of State}

The PC-SAFT equation of state was used to model the properties of mTBD and three of the compounds used for comparison: 1,5-diazabicyclo(4.3.0)non-5-ene (DBN), 1,8diazabicyclo[5.4.0] undec-7-ene (DBU), and 1,1,3,3-tetramethylguanidine (TMG). Our code for implementing PC-SAFT is available on GitHub (https://github.com/ zmeri/PC-SAFT). We verified our code to ensure we got results that matched reference data and the values given by PC-SAFT code from other authors, and the code to perform these checks is included in the GitHub repository.

The PC-SAFT parameters were determined by optimizing the equation of state parameters using vapor pressure and density data. For mTBD, the experimental data presented in this article were used. Literature data were used for DBN, DBU, and TMG [28-32]. To solve for the parameters, we used the differential evolution solver [17] implemented in the SciPy package [18] for Python. For the objective function, the root mean squared error of the vapor pressure and density values were calculated separately and then these were added together to get a final error value to minimize. 


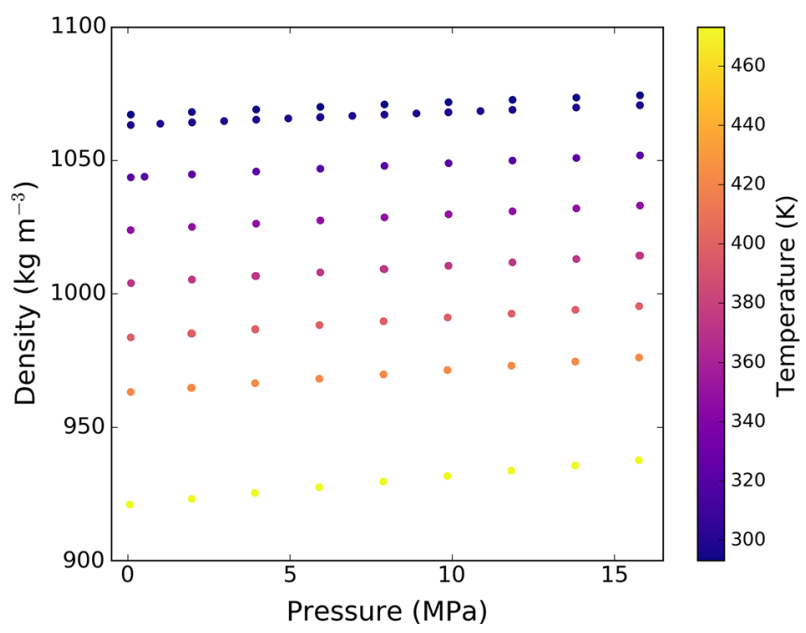

Fig. 2 Density of mTBD as a function of pressure and temperature

DBN and DBU are polar molecules with dipole moments of about 3 Debye, so for these compounds Gross and Vrabec's polar term was included in the PC-SAFT model [33]. Cripwell et al. [34] showed that more reliable parameters for the polar term can be determined if vapor-liquid equilibrium data are included for mixtures of the polar compound with a non-polar compound. However, since no such data are available for DBN and DBU, the number of dipoles was set to be 1, as originally specified by Gross and Vrabec.

\section{Results and Discussion}

\subsection{Liquid Compressed Density and Derivative Properties}

The experimental density data are shown in Fig. 2. The density was measured at temperatures from $293.15 \mathrm{~K}$ to $473.15 \mathrm{~K}$ and at pressures from 0.092 $\mathrm{MPa}$ to $15.788 \mathrm{MPa}$. A file containing these data can be found from the Open Science Framework page for this project (https://osf.io/z4b2p/) and in Table 2. No density data were found in the scientific literature. The only value we could find came from the safety data sheets for mTBD, which state that the density at $298 \mathrm{~K}$ is $1067 \mathrm{~kg} \cdot \mathrm{m}^{-3}$. Although this is in the same range as the value we obtained $\left(1063.35 \pm 0.082 \mathrm{~kg} \cdot \mathrm{m}^{-3}\right.$ at $298 \mathrm{~K}$ and $101000 \mathrm{~Pa}$ ), the difference is still several times larger than the expanded uncertainty of our data.

A polynomial equation (Eq. 5) was fit to the density data so that density could be calculated more accurately than with the PC-SAFT equation of state

$\rho=C_{1}+C_{2} \cdot T+C_{3} \cdot P+C_{4} \cdot P^{2}+C_{5} \cdot T \cdot P+C_{6} \cdot T^{2}+C_{7} \cdot T^{2} \cdot P+C_{8} \cdot T \cdot P^{2}+C_{9} \cdot T^{3}$. 
Table 2 Compressed densities of mTBD, thermal expansion coefficient, and isothermal compressibility

\begin{tabular}{|c|c|c|c|c|c|c|}
\hline $\begin{array}{l}\text { Temperature } \\
\text { (K) }\end{array}$ & $\begin{array}{l}\text { Pressure } \\
(\mathrm{MPa})\end{array}$ & $\begin{array}{l}\text { Density } \\
\left(\mathrm{kg} \cdot \mathrm{m}^{-3}\right)\end{array}$ & $\begin{array}{l}\text { Thermal } \\
\text { expansion } \\
\text { coefficient } \\
\left(\mathrm{K}^{-1}\right)\end{array}$ & $\begin{array}{l}\text { Expanded } \\
\text { uncertainty } \\
\text { of thermal } \\
\text { expansion } \\
\text { coefficient } \\
\left(\mathrm{K}^{-1}\right)\end{array}$ & $\begin{array}{l}\text { Isothermal } \\
\text { compress- } \\
\text { ibility } \\
\left(\mathrm{MPa}^{-1}\right)\end{array}$ & $\begin{array}{l}\text { Expanded } \\
\text { uncertainty of } \\
\text { isothermal } \\
\text { compressibility } \\
\left(\mathrm{MPa}^{-1}\right)\end{array}$ \\
\hline 293.15 & 0.092 & 1067.24 & $7.32 \mathrm{E}-04$ & $1.3 \mathrm{E}-06$ & $4.72 \mathrm{E}-04$ & $8.9 \mathrm{E}-06$ \\
\hline 293.15 & 1.975 & 1068.21 & $7.28 \mathrm{E}-04$ & $1.2 \mathrm{E}-06$ & $4.63 \mathrm{E}-04$ & $7.0 \mathrm{E}-06$ \\
\hline 293.15 & 3.956 & 1069.15 & $7.24 \mathrm{E}-04$ & $1.2 \mathrm{E}-06$ & $4.53 \mathrm{E}-04$ & $5.2 \mathrm{E}-06$ \\
\hline 293.15 & 5.934 & 1070.13 & $7.20 \mathrm{E}-04$ & $1.1 \mathrm{E}-06$ & $4.43 \mathrm{E}-04$ & $3.6 \mathrm{E}-06$ \\
\hline 293.15 & 7.911 & 1071.05 & $7.16 \mathrm{E}-04$ & $1.1 \mathrm{E}-06$ & $4.33 \mathrm{E}-04$ & $2.8 \mathrm{E}-06$ \\
\hline 293.15 & 9.885 & 1071.9 & $7.13 \mathrm{E}-04$ & $1.1 \mathrm{E}-06$ & $4.23 \mathrm{E}-04$ & $3.5 \mathrm{E}-06$ \\
\hline 293.15 & 11.858 & 1072.79 & $7.09 \mathrm{E}-04$ & $1.1 \mathrm{E}-06$ & $4.13 \mathrm{E}-04$ & $5.0 \mathrm{E}-06$ \\
\hline 293.15 & 13.823 & 1073.62 & $7.06 \mathrm{E}-04$ & $1.2 \mathrm{E}-06$ & $4.03 \mathrm{E}-04$ & $6.8 \mathrm{E}-06$ \\
\hline 293.15 & 15.786 & 1074.48 & $7.02 \mathrm{E}-04$ & $1.3 \mathrm{E}-06$ & $3.93 \mathrm{E}-04$ & $8.6 \mathrm{E}-06$ \\
\hline 298.15 & 1.980 & 1064.27 & $7.31 \mathrm{E}-04$ & $1.1 \mathrm{E}-06$ & $4.73 \mathrm{E}-04$ & $6.6 \mathrm{E}-06$ \\
\hline 298.15 & 5.927 & 1066.2 & $7.23 \mathrm{E}-04$ & $9.9 \mathrm{E}-07$ & $4.52 \mathrm{E}-04$ & $3.3 \mathrm{E}-06$ \\
\hline 298.15 & 9.877 & 1068.09 & $7.15 \mathrm{E}-04$ & $9.8 \mathrm{E}-07$ & $4.32 \mathrm{E}-04$ & $3.2 \mathrm{E}-06$ \\
\hline 298.15 & 15.781 & 1070.77 & $7.04 \mathrm{E}-04$ & $1.1 \mathrm{E}-06$ & $4.02 \mathrm{E}-04$ & $8.3 \mathrm{E}-06$ \\
\hline 298.15 & 0.091 & 1063.33 & $7.35 \mathrm{E}-04$ & $1.2 \mathrm{E}-06$ & $4.83 \mathrm{E}-04$ & $8.5 \mathrm{E}-06$ \\
\hline 298.15 & 1.002 & 1063.82 & $7.33 \mathrm{E}-04$ & $1.1 \mathrm{E}-06$ & $4.78 \mathrm{E}-04$ & $7.6 \mathrm{E}-06$ \\
\hline 298.15 & 13.819 & 1069.9 & $7.08 \mathrm{E}-04$ & $1.0 \mathrm{E}-06$ & $4.12 \mathrm{E}-04$ & $6.5 \mathrm{E}-06$ \\
\hline 298.15 & 15.785 & 1070.76 & $7.04 \mathrm{E}-04$ & $1.1 \mathrm{E}-06$ & $4.02 \mathrm{E}-04$ & $8.3 \mathrm{E}-06$ \\
\hline 298.15 & 1.983 & 1064.34 & $7.31 \mathrm{E}-04$ & $1.1 \mathrm{E}-06$ & $4.73 \mathrm{E}-04$ & $6.6 \mathrm{E}-06$ \\
\hline 298.15 & 2.968 & 1064.82 & $7.29 \mathrm{E}-04$ & $1.0 \mathrm{E}-06$ & $4.68 \mathrm{E}-04$ & $5.7 \mathrm{E}-06$ \\
\hline 298.15 & 3.957 & 1065.34 & $7.27 \mathrm{E}-04$ & $1.0 \mathrm{E}-06$ & $4.63 \mathrm{E}-04$ & $4.9 \mathrm{E}-06$ \\
\hline 298.15 & 4.946 & 1065.8 & $7.25 \mathrm{E}-04$ & $1.0 \mathrm{E}-06$ & $4.58 \mathrm{E}-04$ & $4.1 \mathrm{E}-06$ \\
\hline 298.15 & 5.935 & 1066.31 & $7.23 \mathrm{E}-04$ & $9.8 \mathrm{E}-07$ & $4.52 \mathrm{E}-04$ & $3.3 \mathrm{E}-06$ \\
\hline 298.15 & 6.920 & 1066.77 & $7.21 \mathrm{E}-04$ & $9.8 \mathrm{E}-07$ & $4.47 \mathrm{E}-04$ & $2.8 \mathrm{E}-06$ \\
\hline 298.15 & 7.909 & 1067.23 & $7.19 \mathrm{E}-04$ & $9.7 \mathrm{E}-07$ & $4.42 \mathrm{E}-04$ & $2.5 \mathrm{E}-06$ \\
\hline 298.15 & 8.896 & 1067.68 & $7.17 \mathrm{E}-04$ & $9.7 \mathrm{E}-07$ & $4.37 \mathrm{E}-04$ & $2.7 \mathrm{E}-06$ \\
\hline 298.15 & 9.884 & 1068.13 & $7.15 \mathrm{E}-04$ & $9.9 \mathrm{E}-07$ & $4.32 \mathrm{E}-04$ & $3.2 \mathrm{E}-06$ \\
\hline 298.15 & 10.869 & 1068.58 & $7.14 \mathrm{E}-04$ & $1.0 \mathrm{E}-06$ & $4.27 \mathrm{E}-04$ & $3.9 \mathrm{E}-06$ \\
\hline 298.15 & 11.855 & 1069.02 & $7.12 \mathrm{E}-04$ & $1.0 \mathrm{E}-06$ & $4.22 \mathrm{E}-04$ & $4.7 \mathrm{E}-06$ \\
\hline 323.15 & 0.092 & 1043.69 & $7.55 \mathrm{E}-04$ & $6.3 \mathrm{E}-07$ & $5.42 \mathrm{E}-04$ & $6.8 \mathrm{E}-06$ \\
\hline 323.15 & 0.516 & 1043.93 & $7.53 \mathrm{E}-04$ & $6.0 \mathrm{E}-07$ & $5.39 \mathrm{E}-04$ & $6.5 \mathrm{E}-06$ \\
\hline 323.15 & 1.977 & 1044.79 & $7.50 \mathrm{E}-04$ & $5.0 \mathrm{E}-07$ & $5.31 \mathrm{E}-04$ & $5.4 \mathrm{E}-06$ \\
\hline 323.15 & 3.956 & 1045.87 & $7.45 \mathrm{E}-04$ & $4.4 \mathrm{E}-07$ & $5.20 \mathrm{E}-04$ & $3.9 \mathrm{E}-06$ \\
\hline 323.15 & 5.933 & 1046.94 & $7.39 \mathrm{E}-04$ & $4.1 \mathrm{E}-07$ & $5.09 \mathrm{E}-04$ & $2.6 \mathrm{E}-06$ \\
\hline 323.15 & 7.910 & 1048 & $7.35 \mathrm{E}-04$ & $4.1 \mathrm{E}-07$ & $4.98 \mathrm{E}-04$ & $1.9 \mathrm{E}-06$ \\
\hline 323.15 & 9.886 & 1049 & $7.30 \mathrm{E}-04$ & $4.2 \mathrm{E}-07$ & $4.87 \mathrm{E}-04$ & $2.5 \mathrm{E}-06$ \\
\hline
\end{tabular}


Table 2 continued

\begin{tabular}{|c|c|c|c|c|c|c|}
\hline $\begin{array}{l}\text { Temperature } \\
(\mathrm{K})\end{array}$ & $\begin{array}{l}\text { Pressure } \\
(\mathrm{MPa})\end{array}$ & $\begin{array}{l}\text { Density } \\
\left(\mathrm{kg} \cdot \mathrm{m}^{-3}\right)\end{array}$ & $\begin{array}{l}\text { Thermal } \\
\text { expansion } \\
\text { coefficient } \\
\left(\mathrm{K}^{-1}\right)\end{array}$ & $\begin{array}{l}\text { Expanded } \\
\text { uncertainty } \\
\text { of thermal } \\
\text { expansion } \\
\text { coefficient } \\
\left(\mathrm{K}^{-1}\right)\end{array}$ & $\begin{array}{l}\text { Isothermal } \\
\text { compress- } \\
\text { ibility } \\
\left(\mathrm{MPa}^{-1}\right)\end{array}$ & $\begin{array}{l}\text { Expanded } \\
\text { uncertainty of } \\
\text { isothermal } \\
\text { compressibility } \\
\left(\mathrm{MPa}^{-1}\right)\end{array}$ \\
\hline 323.15 & 11.855 & 1049.99 & $7.25 \mathrm{E}-04$ & $4.5 \mathrm{E}-07$ & $4.76 \mathrm{E}-04$ & $3.8 \mathrm{E}-06$ \\
\hline 323.15 & 13.824 & 1050.96 & $7.20 \mathrm{E}-04$ & $5.0 \mathrm{E}-07$ & $4.65 \mathrm{E}-04$ & $5.3 \mathrm{E}-06$ \\
\hline 323.15 & 15.786 & 1051.93 & $7.16 \mathrm{E}-04$ & $6.3 \mathrm{E}-07$ & $4.54 \mathrm{E}-04$ & $6.8 \mathrm{E}-06$ \\
\hline 348.15 & 11.856 & 1030.95 & $7.40 \mathrm{E}-04$ & $3.4 \mathrm{E}-07$ & $5.42 \mathrm{E}-04$ & $3.7 \mathrm{E}-06$ \\
\hline 348.15 & 13.824 & 1032.03 & $7.35 \mathrm{E}-04$ & $3.8 \mathrm{E}-07$ & $5.30 \mathrm{E}-04$ & $4.9 \mathrm{E}-06$ \\
\hline 348.15 & 15.786 & 1033.11 & $7.29 \mathrm{E}-04$ & $4.9 \mathrm{E}-07$ & $5.18 \mathrm{E}-04$ & $6.2 \mathrm{E}-06$ \\
\hline 348.15 & 0.087 & 1023.91 & $7.76 \mathrm{E}-04$ & $4.6 \mathrm{E}-07$ & $6.14 \mathrm{E}-04$ & $6.3 \mathrm{E}-06$ \\
\hline 348.15 & 1.978 & 1025.09 & $7.70 \mathrm{E}-04$ & $3.5 \mathrm{E}-07$ & $6.03 \mathrm{E}-04$ & $5.0 \mathrm{E}-06$ \\
\hline 348.15 & 3.954 & 1026.31 & $7.64 \mathrm{E}-04$ & $3.2 \mathrm{E}-07$ & $5.90 \mathrm{E}-04$ & $3.7 \mathrm{E}-06$ \\
\hline 348.15 & 5.933 & 1027.52 & $7.58 \mathrm{E}-04$ & $3.2 \mathrm{E}-07$ & $5.78 \mathrm{E}-04$ & $2.6 \mathrm{E}-06$ \\
\hline 348.15 & 7.911 & 1028.67 & $7.52 \mathrm{E}-04$ & $3.3 \mathrm{E}-07$ & $5.66 \mathrm{E}-04$ & $2.1 \mathrm{E}-06$ \\
\hline 348.15 & 9.885 & 1029.81 & $7.46 \mathrm{E}-04$ & $3.3 \mathrm{E}-07$ & $5.54 \mathrm{E}-04$ & $2.6 \mathrm{E}-06$ \\
\hline 373.15 & 1.977 & 1005.3 & $7.94 \mathrm{E}-04$ & $4.7 \mathrm{E}-07$ & $6.88 \mathrm{E}-04$ & $5.3 \mathrm{E}-06$ \\
\hline 373.15 & 15.788 & 1014.31 & $7.44 \mathrm{E}-04$ & $5.5 \mathrm{E}-07$ & $5.96 \mathrm{E}-04$ & $6.8 \mathrm{E}-06$ \\
\hline 373.15 & 3.930 & 1006.66 & $7.86 \mathrm{E}-04$ & $4.5 \mathrm{E}-07$ & $6.75 \mathrm{E}-04$ & $4.0 \mathrm{E}-06$ \\
\hline 373.15 & 7.884 & 1009.3 & $7.72 \mathrm{E}-04$ & $4.7 \mathrm{E}-07$ & $6.49 \mathrm{E}-04$ & $2.5 \mathrm{E}-06$ \\
\hline 373.15 & 15.764 & 1014.35 & $7.44 \mathrm{E}-04$ & $5.4 \mathrm{E}-07$ & $5.97 \mathrm{E}-04$ & $6.7 \mathrm{E}-06$ \\
\hline 373.15 & 13.822 & 1013.03 & $7.51 \mathrm{E}-04$ & $4.8 \mathrm{E}-07$ & $6.09 \mathrm{E}-04$ & $5.4 \mathrm{E}-06$ \\
\hline 373.15 & 11.855 & 1011.8 & $7.58 \mathrm{E}-04$ & $4.7 \mathrm{E}-07$ & $6.22 \mathrm{E}-04$ & $4.1 \mathrm{E}-06$ \\
\hline 373.15 & 7.908 & 1009.22 & $7.72 \mathrm{E}-04$ & $4.8 \mathrm{E}-07$ & $6.49 \mathrm{E}-04$ & $2.5 \mathrm{E}-06$ \\
\hline 373.15 & 9.883 & 1010.51 & $7.65 \mathrm{E}-04$ & $4.7 \mathrm{E}-07$ & $6.36 \mathrm{E}-04$ & $3.0 \mathrm{E}-06$ \\
\hline 373.15 & 3.954 & 1006.68 & $7.86 \mathrm{E}-04$ & $4.6 \mathrm{E}-07$ & $6.75 \mathrm{E}-04$ & $4.0 \mathrm{E}-06$ \\
\hline 373.15 & 5.932 & 1008.03 & $7.79 \mathrm{E}-04$ & $4.7 \mathrm{E}-07$ & $6.62 \mathrm{E}-04$ & $2.9 \mathrm{E}-06$ \\
\hline 373.15 & 1.976 & 1005.33 & $7.94 \mathrm{E}-04$ & $4.7 \mathrm{E}-07$ & $6.88 \mathrm{E}-04$ & $5.3 \mathrm{E}-06$ \\
\hline 373.16 & 0.098 & 1004 & $8.01 \mathrm{E}-04$ & $5.3 \mathrm{E}-07$ & $7.01 \mathrm{E}-04$ & $6.6 \mathrm{E}-06$ \\
\hline 398.15 & 9.857 & 991.11 & $7.86 \mathrm{E}-04$ & $4.8 \mathrm{E}-07$ & $7.32 \mathrm{E}-04$ & $3.2 \mathrm{E}-06$ \\
\hline 398.15 & 11.827 & 992.54 & $7.78 \mathrm{E}-04$ & $4.7 \mathrm{E}-07$ & $7.18 \mathrm{E}-04$ & $4.5 \mathrm{E}-06$ \\
\hline 398.15 & 13.795 & 993.97 & $7.70 \mathrm{E}-04$ & $4.9 \mathrm{E}-07$ & $7.04 \mathrm{E}-04$ & $6.2 \mathrm{E}-06$ \\
\hline 398.15 & 0.091 & 983.79 & $8.28 \mathrm{E}-04$ & $5.6 \mathrm{E}-07$ & $8.03 \mathrm{E}-04$ & $7.7 \mathrm{E}-06$ \\
\hline 398.15 & 1.956 & 985.23 & $8.20 \mathrm{E}-04$ & $4.8 \mathrm{E}-07$ & $7.90 \mathrm{E}-04$ & $6.0 \mathrm{E}-06$ \\
\hline 398.15 & 15.758 & 995.35 & $7.62 \mathrm{E}-04$ & $5.7 \mathrm{E}-07$ & $6.89 \mathrm{E}-04$ & $7.8 \mathrm{E}-06$ \\
\hline 398.15 & 7.882 & 989.67 & $7.95 \mathrm{E}-04$ & $4.6 \mathrm{E}-07$ & $7.46 \mathrm{E}-04$ & $2.6 \mathrm{E}-06$ \\
\hline 398.15 & 1.979 & 985.22 & $8.20 \mathrm{E}-04$ & $4.9 \mathrm{E}-07$ & $7.90 \mathrm{E}-04$ & $6.0 \mathrm{E}-06$ \\
\hline 398.15 & 3.928 & 986.76 & $8.11 \mathrm{E}-04$ & $4.6 \mathrm{E}-07$ & $7.75 \mathrm{E}-04$ & $4.4 \mathrm{E}-06$ \\
\hline 398.15 & 5.907 & 988.24 & $8.03 \mathrm{E}-04$ & $4.6 \mathrm{E}-07$ & $7.61 \mathrm{E}-04$ & $3.2 \mathrm{E}-06$ \\
\hline 423.14 & 9.853 & 971.53 & $8.10 \mathrm{E}-04$ & $3.9 \mathrm{E}-07$ & $8.44 \mathrm{E}-04$ & $3.5 \mathrm{E}-06$ \\
\hline
\end{tabular}


Table 2 continued

\begin{tabular}{|c|c|c|c|c|c|c|}
\hline $\begin{array}{l}\text { Temperature } \\
(\mathrm{K})\end{array}$ & $\begin{array}{l}\text { Pressure } \\
(\mathrm{MPa})\end{array}$ & $\begin{array}{l}\text { Density } \\
\left(\mathrm{kg} \cdot \mathrm{m}^{-3}\right)\end{array}$ & $\begin{array}{l}\text { Thermal } \\
\text { expansion } \\
\text { coefficient } \\
\left(\mathrm{K}^{-1}\right)\end{array}$ & $\begin{array}{l}\text { Expanded } \\
\text { uncertainty } \\
\text { of thermal } \\
\text { expansion } \\
\text { coefficient } \\
\left(\mathrm{K}^{-1}\right)\end{array}$ & $\begin{array}{l}\text { Isothermal } \\
\text { compress- } \\
\text { ibility } \\
\left(\mathrm{MPa}^{-1}\right)\end{array}$ & $\begin{array}{l}\text { Expanded } \\
\text { uncertainty of } \\
\text { isothermal } \\
\text { compressibility } \\
\left(\mathrm{MPa}^{-1}\right)\end{array}$ \\
\hline 423.14 & 11.824 & 973.14 & $8.01 \mathrm{E}-04$ & $4.2 \mathrm{E}-07$ & $8.28 \mathrm{E}-04$ & $5.3 \mathrm{E}-06$ \\
\hline 423.14 & 0.090 & 963.3 & $8.59 \mathrm{E}-04$ & $5.9 \mathrm{E}-07$ & $9.22 \mathrm{E}-04$ & $9.8 \mathrm{E}-06$ \\
\hline 423.15 & 1.973 & 964.87 & $8.49 \mathrm{E}-04$ & $4.7 \mathrm{E}-07$ & $9.07 \mathrm{E}-04$ & $7.6 \mathrm{E}-06$ \\
\hline 423.15 & 13.791 & 974.7 & $7.92 \mathrm{E}-04$ & $4.9 \mathrm{E}-07$ & $8.13 \mathrm{E}-04$ & $7.3 \mathrm{E}-06$ \\
\hline 423.15 & 15.755 & 976.23 & $7.83 \mathrm{E}-04$ & $6.4 \mathrm{E}-07$ & $7.98 \mathrm{E}-04$ & $9.5 \mathrm{E}-06$ \\
\hline 423.15 & 3.923 & 966.61 & $8.39 \mathrm{E}-04$ & $3.9 \mathrm{E}-07$ & $8.91 \mathrm{E}-04$ & $5.4 \mathrm{E}-06$ \\
\hline 423.15 & 5.902 & 968.27 & $8.30 \mathrm{E}-04$ & $3.6 \mathrm{E}-07$ & $8.75 \mathrm{E}-04$ & $3.5 \mathrm{E}-06$ \\
\hline 423.16 & 7.881 & 969.88 & $8.20 \mathrm{E}-04$ & $3.8 \mathrm{E}-07$ & $8.60 \mathrm{E}-04$ & $2.6 \mathrm{E}-06$ \\
\hline 423.16 & 1.949 & 964.85 & $8.49 \mathrm{E}-04$ & $4.7 \mathrm{E}-07$ & $9.07 \mathrm{E}-04$ & $7.7 \mathrm{E}-06$ \\
\hline 473.14 & 5.898 & 927.56 & $8.92 \mathrm{E}-04$ & $1.4 \mathrm{E}-06$ & $1.16 \mathrm{E}-03$ & $6.4 \mathrm{E}-06$ \\
\hline 473.14 & 7.875 & 929.67 & $8.80 \mathrm{E}-04$ & $1.4 \mathrm{E}-06$ & $1.14 \mathrm{E}-03$ & $5.2 \mathrm{E}-06$ \\
\hline 473.15 & 0.062 & 921.05 & $9.30 \mathrm{E}-04$ & $1.7 \mathrm{E}-06$ & $1.21 \mathrm{E}-03$ & $1.5 \mathrm{E}-05$ \\
\hline 473.15 & 1.972 & 923.2 & $9.18 \mathrm{E}-04$ & $1.5 \mathrm{E}-06$ & $1.20 \mathrm{E}-03$ & $1.2 \mathrm{E}-05$ \\
\hline 473.15 & 3.919 & 925.4 & $9.05 \mathrm{E}-04$ & $1.5 \mathrm{E}-06$ & $1.18 \mathrm{E}-03$ & $9.0 \mathrm{E}-06$ \\
\hline 473.15 & 13.788 & 935.74 & $8.43 \mathrm{E}-04$ & $1.6 \mathrm{E}-06$ & $1.08 \mathrm{E}-03$ & $1.1 \mathrm{E}-05$ \\
\hline 473.15 & 15.751 & 937.7 & $8.31 \mathrm{E}-04$ & $1.7 \mathrm{E}-06$ & $1.06 \mathrm{E}-03$ & $1.5 \mathrm{E}-05$ \\
\hline 473.15 & 9.851 & 931.74 & $8.67 \mathrm{E}-04$ & $1.4 \mathrm{E}-06$ & $1.12 \mathrm{E}-03$ & $6.1 \mathrm{E}-06$ \\
\hline 473.15 & 11.82 & 933.78 & $8.55 \mathrm{E}-04$ & $1.5 \mathrm{E}-06$ & $1.10 \mathrm{E}-03$ & $8.4 \mathrm{E}-06$ \\
\hline 473.15 & 3.919 & 925.38 & $9.05 \mathrm{E}-04$ & $1.5 \mathrm{E}-06$ & $1.18 \mathrm{E}-03$ & $9.0 \mathrm{E}-06$ \\
\hline
\end{tabular}

Standard uncertainty of the density: $\mathrm{u}\left(\right.$ density) $=0.040 \mathrm{~kg} \cdot \mathrm{m}^{-3}$ (expanded uncertainty $\mathrm{u}($ density) $=$ $0.082 \mathrm{~kg} \cdot \mathrm{m}^{-3}$ at the $95 \%$ level). Standard uncertainty of temperature u(temperature) $=0.1 \mathrm{~K}$ (expanded uncertainty $\mathrm{u}$ (temperature) $=0.2 \mathrm{~K}$ at the $95 \%$ level). The standard uncertainty of the pressure is $\mathrm{u}$ (pressure) $=3100 \mathrm{~Pa}$ (expanded uncertainty $\mathrm{u}($ pressure $)=6300 \mathrm{~Pa}$ at the $95 \%$ level $)$

In Eq. 5, $\rho$ is the density $\left(\mathrm{kg} \cdot \mathrm{m}^{-3}\right)$, $\mathrm{T}$ is the temperature $(\mathrm{K}), \mathrm{P}$ is the pressure $(\mathrm{MPa})$, and the $\mathrm{C}$ values are constants. These equation constants are given in Table 3 . This equation is valid over the range of the experimental density data, so from $293 \mathrm{~K}$ to $473 \mathrm{~K}$ and from $90000 \mathrm{~Pa}$ to $15700000 \mathrm{~Pa}$. The root mean squared error (RMSE) of Eq. 5 is $0.035 \mathrm{~kg} \cdot \mathrm{m}^{-3}$, when compared to the experimental data, and the maximum deviation was $0.073 \mathrm{~kg} \cdot \mathrm{m}^{-3}$. The constants were determined using the differential evolution solver [17] implemented in the SciPy package [18] for Python.

Using this more accurate polynomial fit, derivative properties could be calculated more reliably than with the PC-SAFT equation of state. The thermal expansion coefficient and the isothermal compressibility were calculated by taking the appropriate derivatives of Eq. 5, and the resulting data are also given in the same file as the density data (https://osf.io/jb8y7/). The expanded uncertainties of the thermal expansion coefficient and the isothermal compressibility were calculated using the same Monte 
Table 3 Constants for polynomial density equation

\begin{tabular}{lr}
\hline $\mathrm{C}_{1}$ & $1.29934399 \times 10^{3}$ \\
$\mathrm{C}_{2}$ & $-8.40839641 \times 10^{-1}$ \\
$\mathrm{C}_{3}$ & $7.71488318 \times 10^{-1}$ \\
$\mathrm{C}_{4}$ & $-5.84175802 \times 10^{-4}$ \\
$\mathrm{C}_{5}$ & $-3.58906385 \times 10^{-3}$ \\
$\mathrm{C}_{6}$ & $2.96880106 \times 10^{-4}$ \\
$\mathrm{C}_{7}$ & $9.13797725 \times 10^{-6}$ \\
$\mathrm{C}_{8}$ & $-6.89083285 \times 10^{-6}$ \\
$\mathrm{C}_{9}$ & $-4.42874998 \times 10^{-7}$ \\
\hline
\end{tabular}

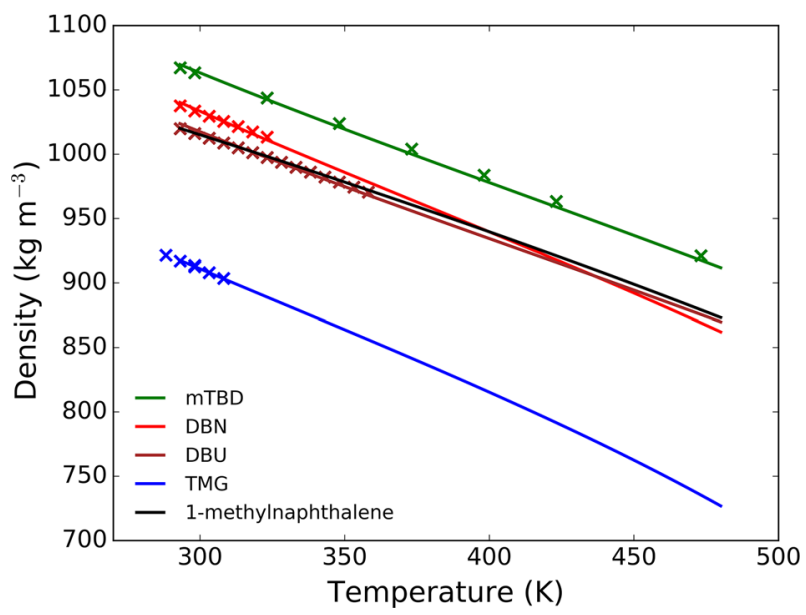

Fig. 3 Comparison of the densities of mTBD and other similar compounds at $0.1 \mathrm{MPa}$. The $\mathrm{x}$ markers indicate experimental data points. (mTBD, x, this work; DBN, x, [29]; DBU, x, [30]; TMG, x, [31]), the lines indicate model: mTBD, -; DBN, -; DBU, -; TMG, -;1-methylnaphthalene [35], - (Color figure online)

Carlo method used for calculating the vapor pressure uncertainties. The Python code used for this calculation can be found from the OSF project for this study (https://osf. io/273tq/).

We compared the density of mTBD to that of some structurally similar compounds, as shown in Fig. 3. For DBN, DBU and TMG PC-SAFT parameters were fit in this study using literature data [29-33] (see Sect. 3.7), and PC-SAFT was then used for calculating values for comparison. The one exception was 1-methylnaphthalene, for which values were taken from the DIPPR correlation [35]. mTBD had a higher density than any of the compounds considered in this work.

\subsection{Vapor Pressure of Liquid}

The vapor pressure was measured at temperatures from $318.23 \mathrm{~K}$ to $451.2 \mathrm{~K}$ and pressures from 11.1 $\mathrm{Pa}$ to $10000 \mathrm{~Pa}$. The measurements were conducted with two 


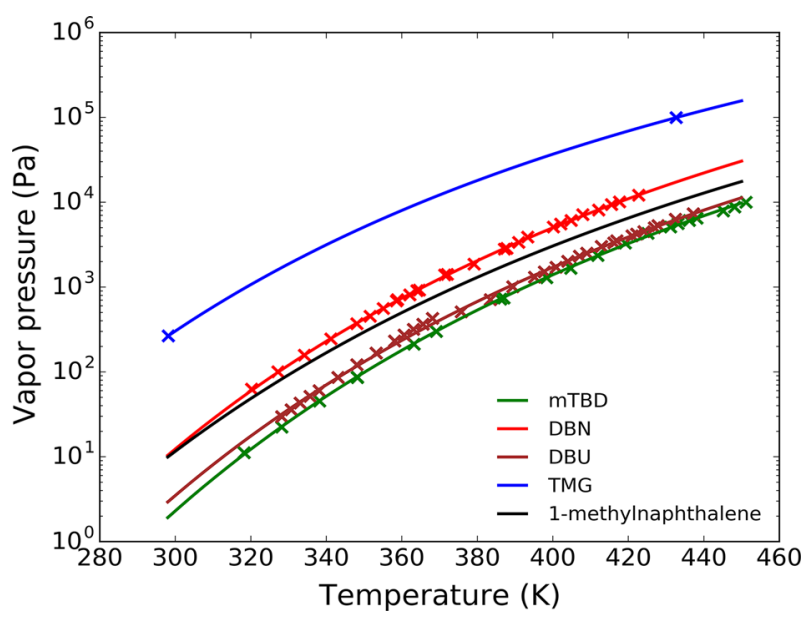

Fig. 4 Vapor pressure of mTBD and comparison with some other compounds. The markers indicate experimental data points (mTBD, $x$; DBN, $x$; DBU, $x$; TMG, $x$ ), the lines indicate model: mTBD, -; DBN, -; DBU, - ;TMG, - ;1-methylnaphthalene [35], - (Color figure online)

methods: the gas saturation method and the distillation method. The experimental vapor pressure data are shown in Fig. 4 and in Table 4. A complete data file can be obtained from the OSF page for this project (https://osf.io/t64dn/), and this file contains the calculations for the gas saturation data. The values for several structurally similar compounds were also plotted for comparison. For most of these other compounds, the values for comparison were calculated using PC-SAFT. The PC-SAFT parameters for these compounds were fit in this study using literature data. For 1-methylnaphthalene, the vapor pressure was calculated using the DIPPR correlation [35].

No vapor pressure data can be found for $\mathrm{MTBD}$ in the literature. Some safety data sheets give a single vapor pressure value of $0.1 \mathrm{hPa}$ (or $0.1 \mathrm{mmHg}$, depending on the sheet) at $348 \mathrm{~K}$ to $352 \mathrm{~K}$. This value is significantly lower than the data measured in this study, which could present a safety issue if the actual vapor pressure is higher than expected.

However, some data for structurally similar compounds can be found in the literature. For comparison, the vapor pressures of these compounds (DBN, DBU, TMG, and 1-methylnaphthalene) are also given in Fig. 4, and as seen, mTBD has a relatively low vapor pressure compared to these other compounds. DBN and DBU can be considered substitutes for mTBD in many applications because they also have similar basic properties and form ionic liquids, so the lower vapor pressure of mTBD may be one factor in deciding which compound to use.

Another interesting comparison is between mTBD and the closely related compound 1,5,7-triazabicyclo[4.4.0]dec-5-ene (TBD). Although no vapor pressure data are publicly available for TBD, when distilling the mTBD the residue in the bottom was enriched in TBD, which indicates that TBD has an even lower vapor pressure than mTBD. 
Table 4 Liquid vapor pressure of mTBD

\begin{tabular}{|c|c|c|c|}
\hline Temperature $^{\mathrm{a}}(\mathrm{K})$ & Vapor pressure $(\mathrm{Pa})$ & $\begin{array}{l}\text { Expanded uncertainty of vapor } \\
\text { pressure at } 95 \% \text { level }(\mathrm{Pa})\end{array}$ & Measurement method \\
\hline 318.23 & 11.1 & 0.13 & Gas saturation \\
\hline 328.21 & 22.4 & 0.27 & Gas saturation \\
\hline 338.21 & 45.2 & 0.54 & Gas saturation \\
\hline 348.20 & 87.2 & 1.1 & Gas saturation \\
\hline 348.22 & 85.6 & 1.0 & Gas saturation \\
\hline 363.23 & 213 & 2.6 & Gas saturation \\
\hline 369.2 & 300 & 200 & Distillation (Helsinki) \\
\hline 386.16 & 722 & 12 & Gas saturation \\
\hline 386.7 & 742 & 28 & Distillation (Aalto) \\
\hline 398.0 & 1287 & 28 & Distillation (Aalto) \\
\hline 404.4 & 1662 & 29 & Distillation (Aalto) \\
\hline 411.6 & 2354.5 & 30 & Distillation (Aalto) \\
\hline 419.2 & 3300 & 330 & Distillation (Helsinki) \\
\hline 425.2 & 4300 & 430 & Distillation (Helsinki) \\
\hline 431.2 & 5100 & 510 & Distillation (Helsinki) \\
\hline 433.2 & 5600 & 560 & Distillation (Helsinki) \\
\hline 436.2 & 6100 & 610 & Distillation (Helsinki) \\
\hline 438.2 & 6500 & 650 & Distillation (Helsinki) \\
\hline 445.2 & 7900 & 790 & Distillation (Helsinki) \\
\hline 448.2 & 8800 & 880 & Distillation (Helsinki) \\
\hline 451.2 & 10000 & 1000 & Distillation (Helsinki) \\
\hline
\end{tabular}

$\mathrm{u}\left(\mathrm{T}_{\text {gas saturation }}\right)=0.04 \mathrm{~K}, \mathrm{u}\left(\mathrm{T}_{\text {distillation, Helsinki }}\right)=1 \mathrm{~K}, \mathrm{u}\left(\mathrm{T}_{\text {distillation Aalto }}\right)=0.12$

${ }^{a}$ The expanded uncertainty of the temperature measurements (at the $95 \%$ level)

\subsection{Liquid Viscosity}

The liquid viscosity ( $290.79 \mathrm{~K}$ to $363.00 \mathrm{~K}$ and atmospheric pressure) is presented in Fig. 5 and Table 5. The data were fit using Eq. 6, which is a form of the Andrade and DIPPR equations [35, 36]. The differential evolution solver [17] implemented in the SciPy package [18] for Python was used to fit the parameters for Eq. 6.

$$
\ln (\eta)=A+\frac{B}{T}+C \cdot \ln (T)
$$

In Eq. 6, $\eta$ is the dynamic viscosity ( $\mathrm{mPa} \cdot \mathrm{s})$, $\mathrm{T}$ is the temperature (K), and $\mathrm{A}$ through $\mathrm{C}$ are constants. The constants fit to the data for $\mathrm{mTBD}$ are as follows: $\mathrm{A}=-118.97$, $\mathrm{B}=7767.2$, and $\mathrm{C}=16.653$. The root mean squared error of Eq. 6 was $4 \%$, and the maximum deviation from the experimental data was $12 \%$.

The viscosity of 1-methylnaphthalene and TMG were also plotted in Fig. 5 for comparison, and mTBD has a higher viscosity than either of these compounds. 


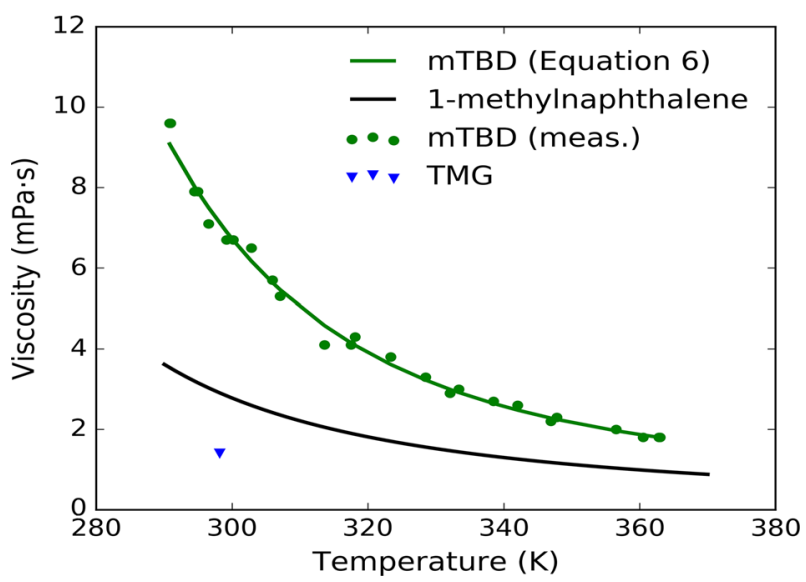

Fig. 5 Viscosity of mTBD ( $\bullet$ ) at $0.1 \mathrm{MPa}$ and comparison with data for TMG [32], $\nabla$; and 1methylnaphthalene [35], - ; mTBD Eq. 6, -(Color figure online)

Table 5 Viscosity of mTBD at pressure $0.1 \mathrm{MPa}$

\begin{tabular}{llll}
\hline Temperature $(\mathrm{K})^{\mathrm{a}}$ & Viscosity $(\mathrm{mPa} \cdot \mathrm{s})^{\mathrm{b}}$ & Temperature $(\mathrm{K})$ & Viscosity $(\mathrm{mPa} \cdot \mathrm{s})$ \\
\hline 296.54 & 7.1 & 305.92 & 5.7 \\
290.79 & 9.6 & 313.58 & 4.1 \\
290.93 & 9.6 & 328.48 & 3.3 \\
302.83 & 6.5 & 338.46 & 2.7 \\
318.08 & 4.3 & 347.79 & 2.3 \\
323.34 & 3.8 & 362.83 & 1.8 \\
323.35 & 3.8 & 294.45 & 7.9 \\
333.35 & 3.0 & 299.18 & 6.7 \\
342.02 & 2.6 & 307.06 & 5.3 \\
356.51 & 2.0 & 317.49 & 4.1 \\
363.00 & 1.8 & 332.05 & 2.9 \\
294.95 & 7.9 & 346.91 & 2.2 \\
300.14 & 6.7 & 360.49 & 1.8 \\
\hline
\end{tabular}

$\mathrm{u}(\mathrm{p})=10 \mathrm{kPa}$, standard uncertainty

${ }^{\mathrm{a}}$ The expanded uncertainty of the temperature increases linearly from $0.04 \mathrm{~K}$ at $293 \mathrm{~K}$ up to $0.2 \mathrm{~K}$ at $363 \mathrm{~K}$

${ }^{\mathrm{b}}$ Standard uncertainty of viscosity: $5.4 \%$; expanded uncertainty (95\% level): $12 \%$

\subsection{Melting Point and Heat of Fusion}

The melting point of mTBD was measured to be $290 \pm 1.2 \mathrm{~K}$ and the heat of fusion is $70 \pm 25 \mathrm{~J} \cdot \mathrm{g}^{-1}$. The thermogram from the DSC measurement is given in Fig. 6. When handling mTBD, we also noticed it can exist for months in a subcooled state. We stored the mTBD samples in the fridge at $277 \pm 2 \mathrm{~K}$ and did not observe freezing. However, when cooled to lower temperatures, the mTBD would freeze and remain solid in the fridge. 


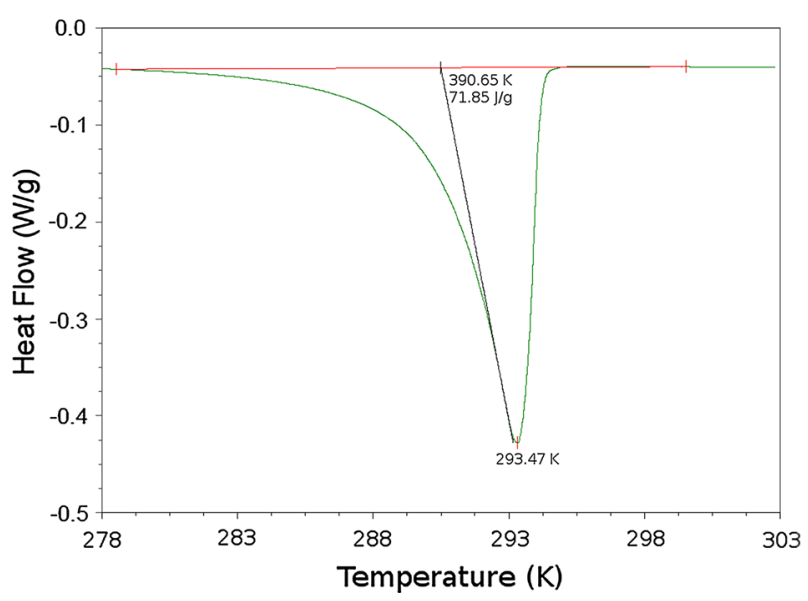

Fig. 6 DSC thermogram showing the melting peak of mTBD

\subsection{Liquid Heat Capacity}

The experimental data for the isobaric liquid heat capacity at $0.36 \mathrm{MPa}$ are given in Table 6 and shown in Fig. 7. Equations of state, such as PC-SAFT, generally only provide the residual heat capacity, and a separate relationship for the ideal gas contribution is needed [15]. Usually ideal gas heat capacities are calculated using a statistical mechanical model and/or spectroscopic data [13,37]. Because such data were not available, we instead used the PC-SAFT equation of state to calculate the residual heat capacity and then subtracted this from the experimental data to determine the ideal gas heat capacity. These ideal gas heat capacity values were then correlated using the Aly-Lee equation (Eq. 7) [37, 38]

$$
C_{\mathrm{p}}^{\mathrm{id}}=A+B\left(\frac{C / T}{\sin h(C / T)}\right)^{2}+D\left(\frac{E / T}{\cos h(E / T)}\right)^{2} .
$$

In Eq. $7, \mathrm{C}_{\mathrm{p}}^{\mathrm{id}}$ is the ideal gas heat capacity $\left(\mathrm{J} \cdot \mathrm{kmol}^{-1} \cdot \mathrm{K}^{-1}\right)$, $\mathrm{T}$ is the temperature $(\mathrm{K})$, and $\mathrm{A}$ through $\mathrm{E}$ are constants. Note that the units for heat capacity are $\mathrm{J} \cdot \mathrm{kmol}^{-1} \cdot \mathrm{K}^{-1}$. The constants for mTBD are given in Table 7.

Because we used an equation of state to calculate the ideal gas heat capacities, any uncertainty from the equation of state is carried over to these ideal gas values. Gross and Sadowski [10] calculated heat capacities for seven compounds using PC-SAFT, and they found that on average the deviation from reference data was $1.7 \%$. So the ideal gas heat capacities given here likely have an uncertainty in the same range.

To improve the performance of the PC-SAFT model when extrapolated above $392 \mathrm{~K}$, the constants $\mathrm{C}, \mathrm{D}$, and $\mathrm{E}$ of the Aly-Lee equation were set to be similar to values found in the DIPPR database [35] for the structurally similar compounds naphthalene and 1-methylnaphthalene. Setting these three constants resulted in a trend that is still at least qualitatively correct at higher temperatures. When all five constants 
Table 6 Liquid isobaric heat capacity at pressure $0.36 \mathrm{MPa}$ and ideal gas heat capacity of mTBD

\begin{tabular}{llll}
\hline Temperature $^{\mathrm{a}}(\mathrm{K})$ & $\begin{array}{l}\text { Heat capacity } \\
\left(\mathrm{J} \cdot \mathrm{mol}^{-1} \cdot \mathrm{K}^{-1}\right)\end{array}$ & $\begin{array}{l}\text { Heat capacity } \\
\left(\mathrm{J} \cdot \mathrm{g}^{-1} \cdot \mathrm{K}^{-1}\right)^{\mathrm{b}}\end{array}$ & $\begin{array}{l}\text { Ideal gas heat capacity } \\
\left(\mathrm{J} \cdot \mathrm{mol}^{-1} \cdot \mathrm{K}^{-1}\right)\end{array}$ \\
\hline 312.33 & 275.8 & 1.800 & 193 \\
312.48 & 275.8 & 1.800 & 193 \\
322.24 & 279.6 & 1.825 & 198 \\
322.38 & 280.3 & 1.829 & 199 \\
332.14 & 284.9 & 1.860 & 205 \\
332.28 & 285.5 & 1.863 & 206 \\
342.03 & 289.7 & 1.891 & 212 \\
342.17 & 290.4 & 1.895 & 212 \\
351.93 & 294.9 & 1.924 & 218 \\
352.06 & 295.3 & 1.927 & 219 \\
361.82 & 299.6 & 1.955 & 224 \\
361.96 & 299.9 & 1.957 & 225 \\
371.71 & 304.2 & 1.986 & 230 \\
371.85 & 304.4 & 1.987 & 230 \\
381.61 & 309.1 & 2.017 & 236 \\
381.74 & 309.2 & 2.018 & 236 \\
391.50 & 313.8 & 2.048 & 242 \\
391.63 & 313.5 & 2.046 & 242 \\
\hline
\end{tabular}

$\mathrm{u}(\mathrm{p})=0.01 \mathrm{MPa}$, standard uncertainty

${ }^{\mathrm{a}} \mathrm{u}($ temperature $)=0.05 \mathrm{~K}$, standard uncertainty

${ }^{\mathrm{b}}$ The standard uncertainty of the heat capacity is $0.0028 \mathrm{~J} \cdot \mathrm{g}^{-1} \cdot \mathrm{K}^{-1}$ (expanded uncertainty of $0.0057 \mathrm{~J} \cdot \mathrm{g}^{-1} \cdot \mathrm{K}^{-1}$ at the $95 \%$ level). The standard uncertainty for the Ideal gas heat capacity is $4.2 \mathrm{~J} \cdot \mathrm{mol}^{-1} \cdot \mathrm{K}^{-1}$. (expanded uncertainty of $8.6 \mathrm{~J} \cdot \mathrm{mol}^{-1} \cdot \mathrm{K}^{-1}$ at the $95 \%$ level)

were optimized, instead of just 2, the Aly-Lee equation gave decreasing heat capacity values above $392 \mathrm{~K}$ and had a shape that was clearly incorrect.

\subsection{Liquid Thermal Conductivity and Refractive Index}

The experimental data for the liquid thermal conductivity of mTBD are given in Table 8 .

The refractive index of mTBD was measured between $293 \mathrm{~K}$ and $343 \mathrm{~K}$. The results are presented in Table 9.

\subsection{Modeling Using PC-SAFT}

The PC-SAFT equation of state reproduced the experimental data well, with an average relative deviation of $0.24 \%$ for density and $2.4 \%$ for vapor pressure. The PC-SAFT parameters determined for mTBD, as well as those for DBN, DBU, and TMG, are 


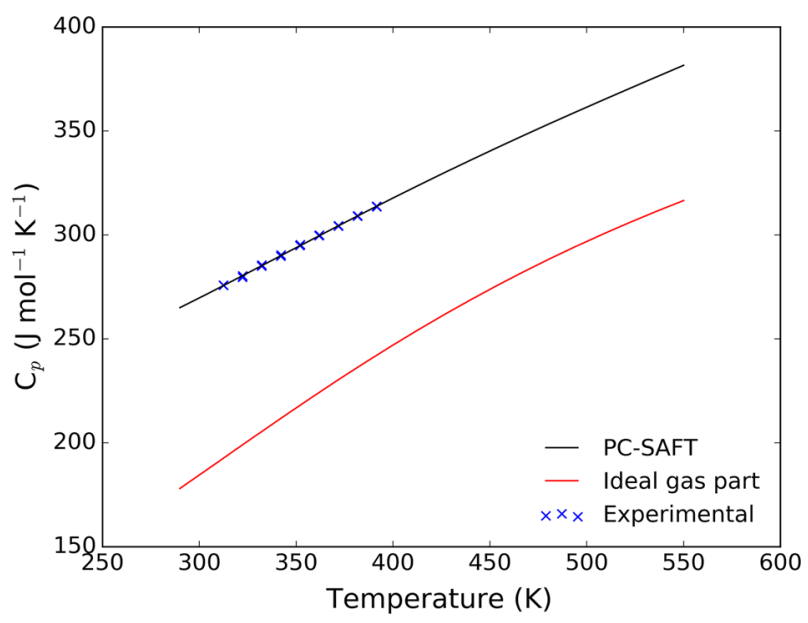

Fig. 7 Liquid isobaric heat capacity of $\operatorname{mTBD}(x)$ and the values calculated using PC-SAFT, -. Ideal gas heat capacities calculated using the Aly-Lee equation $(-)$ are also shown (Color figure online)

Table 7 Constants for Aly-Lee equation for mTBD

\begin{tabular}{lc}
\hline A & 113860 \\
B & 338600 \\
C & 700 \\
D & 100000 \\
E & 3500
\end{tabular}

Constants C, D, and E were fixed based on values for structurally similar compounds. Only A and B were optimized

Table 8 Liquid thermal conductivity of mTBD at pressure $0.1 \mathrm{MPa}$

\begin{tabular}{ll}
\hline Temperature $^{\mathrm{a}}(\mathrm{K})$ & Thermal conductivity $\mathrm{b}\left(\mathrm{W} \cdot \mathrm{m}^{-1} \cdot \mathrm{K}^{-1}\right)$ \\
\hline 299.0 & 0.144 \\
323.8 & 0.140 \\
348.2 & 0.137 \\
372.9 & 0.138 \\
\hline
\end{tabular}

$\mathrm{u}(\mathrm{p})=10 \mathrm{kPa}$, standard uncertainty

$\mathrm{a}_{\mathrm{u}}$ (temperature $)=0.5 \mathrm{~K}$, standard uncertainty

$\mathrm{b}_{\mathrm{u}}$ (thermal Conductivity), expanded uncertainty of $0.007 \mathrm{~W} \cdot \mathrm{m}^{-1} \cdot \mathrm{K}^{-1}$

given in Table 10. Using PC-SAFT, it was possible to estimate the normal boiling point of mTBD, which was calculated to be $536 \mathrm{~K}$. The enthalpy of vaporization can also be calculated using the equation of state and at $298.15 \mathrm{~K}$ it is $67.7 \mathrm{~kJ} \cdot \mathrm{mol}^{-1}$. 
Table 9 Measured liquid refractive index of mTBD at pressure $0.1 \mathrm{MPa}$

\begin{tabular}{ll}
\hline Temperature $^{\mathrm{a}}(\mathrm{K})$ & Refractive index \\
\hline 293.15 & 1.5381 \\
298.15 & 1.5357 \\
303.15 & 1.5338 \\
313.15 & 1.5295 \\
323.15 & 1.5253 \\
333.15 & 1.5211 \\
343.15 & 1.5168
\end{tabular}

Standard uncertainty of liquid refractive index: $\mathrm{u}($ refractive index $)=0.00034$, (expanded uncertainty of 0.000078 at the $95 \%$ level)

$\mathrm{u}(\mathrm{p})=10 \mathrm{kPa}$, standard uncertainty

$\mathrm{a}_{\mathrm{u}} \mathrm{T}(\mathrm{T})=0.03 \mathrm{~K}$, standard uncertainty

Table 10 PC-SAFT parameters for mTBD, DBN, DBU, and TMG

\begin{tabular}{|c|c|c|c|c|c|c|c|c|c|}
\hline & \multirow{2}{*}{$\begin{array}{l}\text { Molar mass } \\
\left(\mathrm{g} \cdot \mathrm{mol}^{-1}\right)\end{array}$} & \multirow[t]{2}{*}{$\mathrm{m}$} & \multirow[t]{2}{*}{$\sigma$} & \multirow[t]{2}{*}{$\varepsilon / \mathrm{k}$} & \multirow[t]{2}{*}{$\mu^{\mathrm{a}}$} & \multirow[t]{2}{*}{$\mathrm{n}_{\mu}$} & \multicolumn{2}{|l|}{$\mathrm{AAD} \%$} & \multirow[t]{2}{*}{ Data refs } \\
\hline & & & & & & & $\mathrm{P}^{\mathrm{sat}}$ & $\rho$ & \\
\hline mTBD & 153.225 & 4.1308 & 3.6822 & 323.47 & - & - & 2.4 & 0.24 & This work \\
\hline DBN & 124.187 & 4.5924 & 3.3138 & 280.37 & $3.29^{\mathrm{a}}$ & 1 & 4.3 & 0.14 & {$[28,29]$} \\
\hline DBU & 152.241 & 3.8212 & 3.8274 & 328.98 & $3.41^{\mathrm{a}}$ & 1 & 4.3 & 0.17 & [28-30] \\
\hline $\mathrm{TMG}^{\mathrm{b}}$ & 115.18 & 4.4477 & 3.3652 & 251.45 & - & - & $0.0080^{\mathrm{b}}$ & 0.047 & {$[31,32]$} \\
\hline
\end{tabular}

$\mathrm{m}$ is the segment number, $\sigma$ is the segment diameter $(\AA), \varepsilon / \mathrm{k}$ is the dispersion energy divided by the Boltzmann constant $(K), \mu$ is the dipole moment, and $n_{\mu}$ is the number of dipole moments

${ }^{\mathrm{a}}$ Dipole moments taken from Chalvet et al. [39]

${ }^{\mathrm{b}}$ Only two vapor pressure and six density points were available for TMG

Table 11 Summary of the properties of mTBD

${ }^{\mathrm{a} C a l c u l a t e d ~ u s i n g ~ P C-S A F T ~}$ equation of state

\begin{tabular}{ll}
\hline Molar mass & $153.225 \mathrm{~g} \cdot \mathrm{mol}^{-1}$ \\
Density at $298.15 \mathrm{~K}$ and $101000 \mathrm{~Pa}$ & $1063.35 \mathrm{~kg} \cdot \mathrm{m}^{-3}$ \\
Normal boiling point $^{\mathrm{a}}$ & $536 \mathrm{~K}$ \\
Enthalpy of vaporization at $298.15 \mathrm{~K}^{\mathrm{a}}$ & $67.7 \mathrm{~kJ} \cdot \mathrm{mol}^{-1}$ \\
Melting point & $290 \mathrm{~K}$ \\
Enthalpy of fusion & $70 \mathrm{~J} \cdot \mathrm{g}$ \\
Viscosity at $298.15 \mathrm{~K}$ & $7.1 \mathrm{mPa} \cdot \mathrm{s}$ \\
Heat capacity at $298.15 \mathrm{~K}^{\mathrm{a}}$ & $1.75 \mathrm{~J} \cdot \mathrm{g}-1 \cdot \mathrm{K}^{-1}$ \\
Thermal conductivity at $299.0 \mathrm{~K}$ & $0.144 \mathrm{~W} \cdot \mathrm{m}^{-1} \cdot \mathrm{K}^{-1}$ \\
Refractive index at $298.15 \mathrm{~K}$ & 1.5357 \\
\hline
\end{tabular}




\section{Conclusions}

This comprehensive study gives the first data on many of the physical and thermodynamic properties of mTBD. Measured data on the liquid vapor pressure, compressed density, liquid heat capacity, melting properties, liquid thermal conductivity, refractive index, and liquid viscosity of mTBD are presented. The experimental data were used to calculate other properties of mTBD: enthalpy of vaporization, thermal expansion, and isothermal compressibility. Based on these data and the PC-SAFT model fit to the data, the properties of mTBD can be summarized (Table 11). PC-SAFT parameters for several structurally similar compounds were also fit as part of this study, which allowed comparison. mTBD had a higher density and lower vapor pressure than DBN, DBU, and TMG.

Acknowledgments Open access funding provided by Aalto University.

Funding Funding was provided by Business Finland (Grant No. 560/31/2017).

Open Access This article is distributed under the terms of the Creative Commons Attribution 4.0 International License (http://creativecommons.org/licenses/by/4.0/), which permits unrestricted use, distribution, and reproduction in any medium, provided you give appropriate credit to the original author(s) and the source, provide a link to the Creative Commons license, and indicate if changes were made.

\section{References}

1. D. Simoni, R. Rondanin, M. Morini, R. Baruchello, F.P. Invidiata, Tetrahedron Lett. 41, 1607 (2000)

2. D. Simoni, M. Rossi, R. Rondanin, A. Mazzali, R. Baruchello, C. Malagutti, M. Roberti, F.P. Invidiata, Org. Lett. 2, 3765 (2000)

3. T. Ishikawa, Superbases for Organic Synthesis: Guanidines, Amidines, Phosphazenes and Related Organocatalysts (Wiley, Nwe York, 2009)

4. U. Schuchardt, R.M. Vargas, G. Gelbard, J. Mol. Catal. Chem. 99, 65 (1995)

5. Z.-Z. Yang, Y.-N. Zhao, L.-N. He, RSC Adv. 1, 545 (2011)

6. J. Sun, W. Cheng, Z. Yang, J. Wang, T. Xu, J. Xin, S. Zhang, Green Chem. 16, 3071 (2014)

7. A. Parviainen, A.W.T. King, I. Mutikainen, M. Hummel, C. Selg, L.K.J. Hauru, H. Sixta, I. Kilpeläinen, Chemsuschem 6, 2161 (2013)

8. A. Parviainen, R. Wahlström, U. Liimatainen, T. Liitiä, S. Rovio, J.K.J. Helminen, U. Hyväkkö, A.W.T. King, A. Suurnäkki, I. Kilpeläinen, RSC Adv. 5, 69728 (2015)

9. H. Sixta, M. Hummel, B.K. Le, I. Kilpeläinen, A.W.T. King, K.J.J. Helminen, S. Hellstén, WO2018138416 (A1) (2 August 2018)

10. J. Gross, G. Sadowski, Ind. Eng. Chem. Res. 40, 1244 (2001)

11. S.-K. Ruokonen, F. Duša, J. Lokajová, I. Kilpeläinen, A.W.T. King, S.K. Wiedmer, J. Chromatogr. A 1405, 178 (2015)

12. W. Ahmad, A. Ostonen, K. Jakobsson, P. Uusi-Kyyny, V. Alopaeus, U. Hyväkkö, A.W.T. King, Chem. Eng. Res. Des. 114, 287 (2016)

13. R. Span, E.W. Lemmon, R.T. Jacobsen, W. Wagner, A. Yokozeki, J. Phys. Chem. Ref. Data 29, 1361 (2000)

14. W. Wagner, A. Pruß, J. Phys. Chem. Ref. Data 31, 387 (2002)

15. I.H. Bell, J. Wronski, S. Quoilin, V. Lemort, Ind. Eng. Chem. Res. 53, 2498 (2014)

16. Thermophysical Properties of Fluid Systems, (National Institute of Standards and Technology), http:// Webbook.Nist.Gov/Chemistry/Fluid/. Accessed 27 Feb 2019 (n.d.)

17. R. Storn, K. Price, J. Glob. Optim. 11, 341 (1997)

18. E. Jones, E. Oliphant, P. Peterson, SciPy: open source scientific tools for python (2001), https://www. scipy.org/. Accessed 20 June 2019 
19. P. Schiebener, J. Straub, J.M.H. Levelt Sengers, J.S. Gallagher, J. Phys. Chem. Ref. Data 19, 677 (1990)

20. Test No. 104: Vapour Pressure, OECD Guidelines for the Testing of Chemicals, Section 1 (OECD Publishing, Paris, 2006)

21. S.P. Verevkin, D. Wandschneider, A. Heintz, J. Chem. Eng. Data 45, 618 (2000)

22. Evaluation of Measurement Data-Supplement 1 to the "Guide to the Expression of Uncertainty in Measurement"-Propagation of Distributions Using a Monte Carlo Method (Joint Committee for Guides in Metrology, 2008). https://www.bipm.org/utils/common/documents/jcgm/JCGM_101_ 2008_E.pdf. Accessed 20 June 2019

23. J.-Y. Coxam, J.R. Quint, J.-P.E. Grolier, J. Chem. Thermodyn. 23, 1075 (1991)

24. E.C.W. Clarke, D.N. Glew, J. Phys. Chem. Ref. Data 18, 545 (1989)

25. W.A. Wakeham, A. Nagashima, J.V. Sengers, International Union of Pure and Applied Chemistry, and Commission on Thermodynamics, Measurement of the Transport Properties of Fluids (Blackwell Scientific Publications, Oxford, 1991)

26. Y.P. Zhang, X.G. Liang, Z. Wang, X.S. Ge, Int. J. Thermophys. 21, 207 (2000)

27. X. Zhang, S. Fujiwara, Z. Qi, M. Fujii, JASMA J. Jpn. Soc. Microgravity Appl. 16, 129 (1999)

28. D. Lipkind, N. Rath, J.S. Chickos, V.A. Pozdeev, S.P. Verevkin, J. Phys. Chem. B 115, 8785 (2011)

29. A. Ostonen, P. Uusi-Kyyny, M. Pakkanen, V. Alopaeus, Fluid Phase Equilibria 408, 79 (2016)

30. A. Ostonen, E. Sapei, P. Uusi-Kyyny, A. Klemelä, V. Alopaeus, Fluid Phase Equilibria 374, 25 (2014)

31. J. Vitorino, F. Agapito, M.F.M. Piedade, C.E.S. Bernardes, H.P. Diogo, J.P. Leal, M.E. Minas da Piedade, J. Chem. Thermodyn. 77, 179 (2014)

32. M.L. Anderson, R.N. Hammer, J. Chem. Eng. Data 12, 442 (1967)

33. J. Gross, J. Vrabec, AIChE J. 52, 1194 (2006)

34. J.T. Cripwell, C.E. Schwarz, A.J. Burger, Fluid Phase Equilibria 449, 156 (2017)

35. DIPPR Project 801-Full Version (Design Institute For Physical Properties, 2017)

36. E.N. da Costa Andrade, Proc. R. Soc. Lond. A 215, 36 (1952)

37. M. Kleiber, Ind. Eng. Chem. Res. 42, 2007 (2003)

38. F.A. Aly, L.L. Lee, Fluid Phase Equilibria 6, 169 (1981)

39. O. Chalvet, R. Daudel, S. Diner, J.P. Malrieu, Atoms and Molecules in the Ground State: Vol. 1: Atoms and Molecules in the Ground State (Springer Science \& Business Media, New York, 2012)

Publisher's Note Springer Nature remains neutral with regard to jurisdictional claims in published maps and institutional affiliations.

\section{Affiliations}

Zachariah Steven Baird ${ }^{1} \cdot$ Artur Dahlberg $^{1} \cdot$ Petri Uusi-Kyyny ${ }^{1}$. Nahla Osmanbegovic ${ }^{1}$. Joanna Witos ${ }^{2,3}$. Jussi Helminen ${ }^{2}$. Daniel Cederkrantz ${ }^{4}$. Paulus Hyväri ${ }^{2}$. Ville Alopaeus ${ }^{1} \cdot$ Ilkka Kilpeläinen $^{2}$. Susanne K. Wiedmer ${ }^{2,3} \cdot$ Herbert Sixta ${ }^{3}$

1 Department of Chemical and Metallurgical Engineering, Aalto University, P.O. Box 16100, 00076 Espoo, Finland

2 Department of Chemistry, University of Helsinki, P. O. Box 55, 00014 Helsinki, Finland

3 Department of Bioproducts and Biosystems, Aalto University, P. O. Box 16300, 00076 Espoo, Finland

4 Thermtest Europe AB, 43268 Veddige, Sweden 